\title{
CALOGÊNESE E TEORES DE FENÓIS E TANINOS TOTAIS EM BARBATIMÃO [Stryphnodendron adstringens (Mart.) Coville]
}

\author{
Callogenesis and contents of total phenols and tannins in barbatimão \\ [Stryphnodendron adsrtingens (Mart.) Coville]
}

\author{
Ana Hortência Fonsêca Castro', Renato Paiva², Amauri Alves de Alvarenga ${ }^{3}$, Stephania Maíra Machado Vitor ${ }^{4}$
}

\begin{abstract}
RESUMO
Atualmente, culturas de células ou de suspensões celulares têm sido frequentemente empregadas para produzir fitoterápicos com maiores concentrações de princípios ativos. O barbatimão é uma importante espécie medicinal do Cerrado, com taninos nas cascas do caule. Objetivando-se induzir calos em barbatimão e avaliar os teores de fenóis e taninos totais, explantes foliares foram inoculados em meio MS suplementado com $30 \mathrm{~g} \mathrm{~L}^{-1}$ sacarose e acrescidos de 2,4-D $(0 ; 4,52 ; 9,05 ; 18,10 \mu \mathrm{M})$ e BAP $(0 ; 4,44 ; 8,88$; $17,75 \mu \mathrm{M}$ ), na presença e ausência de luz. A calogênese ocorreu em meios contendo 2,4-D, na presença de luz. O número de calos não variou com as concentrações de 2,4-D e maiores valores de matérias fresca e seca de calos e teores de fenóis totais foram observados em meios com 9,05 $\mu \mathrm{M}$ e 18,10 $\mu \mathrm{M}$ de 2,4-D, na presença e ausência de luz. Com BAP, a calogênese ocorreu na ausência de luz, com maior produção de calos na presença de 4,44 e 8,88 $\mu \mathrm{M}$ de BAP e maiores valores de matéria fresca e seca em meios com 4,44 $\mu \mathrm{M}$ de BAP. Calos crescidos em meios suplementados 4,44 e 17,75 $\mu \mathrm{M}$ de BAP apresentaram maiores teores de fenóis totais. Não se detectaram taninos, independente do regulador empregado.
\end{abstract}

Termos para indexação: Planta medicinal, cerrado, calos, 2,4-D, BAP, Stryphnodendron adsrtingens, barbatimão.

\begin{abstract}
Recently, cell cultures and cell suspensions have been frequently employed to produce phytotherapics with high amounts of active principles. Barbatimão is a native species from the Cerrado, with tannins in the stem bark. In order to induce callus in barbatimão and evaluate the content of total phenols and tannins, leaf explants were inoculated on MS medium, supplemented with sucrose $30 \mathrm{~g} \mathrm{~L}$ ${ }^{1}$ and 2,4-D $(0,4.52,9.05,18.10 \mu \mathrm{M})$ and BA $(0,4.44,8.88,17.75 \mu \mathrm{M})$, in the presence and absence of light. The callogenesis occurred on medium containing 2,4-D, in the presence of light. The callus number did not alter with the different concentrations of 2,4-D but higher values of dry and fresh matter of the callus and total phenol contents were observed in medium with $9.05 \mu \mathrm{M}$ and $18.10 \mu \mathrm{M}$ of 2,4$\mathrm{D}$, independently of the light treatment. In treatments with BA, the callogenesis occurred in the absence of light and higher callus induction was observed in medium supplemented with 4.44 and $8.88 \mu \mathrm{M}$ BA in the absence of light and higher values of dry and fresh matter of the callus were observed in medium increased with $4.44 \mu \mathrm{M}$ BA. Callus grown on medium supplemented with 4.44 and 17.75 $\mu \mathrm{M}$ BA showed higher total phenol content. Tannins were not detected independently of the regulator used.
\end{abstract}

Index terms: Medicinal plant, savannah, callus, 2,4-D, BA, Stryphnodendron adsrtingens, barbatimão.

(Recebido em 9 de abril de 2007 e aprovado em 26 de fevereiro de 2008)

\section{INTRODUÇÃO}

O barbatimão [Stryphnodendron adstringens (Mart.) Coville], pertencente à família Fabaceae é uma espécie típica do Cerrado brasileiro, com grande distribuição e importância econômica para o estado de Minas Gerais, sendo empregado na medicina popular principalmente devido às suas propriedades adstringentes e cicatrizantes e como agente antiinflamatório (LIMA et al., 1998). Essas atividades estão diretamente associadas aos elevados teores de taninos (20 a 30\%), na casca do caule. Segundo
Almeida et al. (1998), a produção nacional de casca de barbatimão vem decrescendo desde 1988, principalmente no sul de Minas Gerais, devido à exploração indiscriminada pelas indústrias de curtimento do couro. O barbatimão se regenera na natureza por meio de sementes cuja produção ocorre durante poucos meses do ano e o estabelecimento das mudas é prejudicado por condições ambientais desfavoráveis e pelo ataque de patógenos e herbívoros (FRANÇA et al., 1995). Atualmente, pesquisas relacionadas à micropropagação da espécie são escassas e poucos trabalhos, como os de França et al. (1995) e Nicioli (2006)

\footnotetext{
'Bioquímica, Doutora - Curso de Farmácia - Centro Universitário de Lavras/UNILAVRAS - Rua Padre José Poggel, 506 - Centenário - $37200-000$ Lavras, MG - acastro@unilavras.edu.br

²Engenheiro Agrônomo, PhD, Professor - Departamento de Biologia/DBI - Setor de Fisiologia Vegetal/SFV - Universidade Federal de Lavras/UFLA Cx. P. 3037 - 37200-000 - Lavras, MG - renpaiva@ufla.br

${ }^{3}$ Engenheiro Agrônomo, Doutor, Professor - Departamento de Biologia/DBI - Setor de Fisiologia Vegetal/SFV - Universidade Federal de Lavras/UFLA - Cx. P. 3037 - 37200-000 - Lavras, MG - amauriaa@ufla.br

4Bioquímica - Rua Comandante Nélio, 56 - Jardim Floresta - 37200-000 Lavras, MG - smmv@yahoo.com.br
}

Ciênc. agrotec., Lavras, v. 33, n. 2 , p. 385-390, mar./abr., 2009 
relatam resultados satisfatórios relacionados ao cultivo in vitro da espécie.

Nas últimas décadas, o avanço das fronteiras agrícolas e o desmatamento do cerrado para atividades agropecuárias, têm levado muitas espécies ao risco de extinção. Outra ameaça é o extrativismo, com o objetivo de suprir o comércio de plantas medicinais, sendo que mais de $50 \%$ das espécies exportadas pelo Brasil são coletadas em seu ambiente natural, caracterizando muitas vezes um extrativismo predatório (SILVA FILHO, 1992). Segundo Gomes (1999), o estabelecimento de protocolos de propagação proporciona o cultivo em larga escala, favorecendo a comercialização de ervas e os pequenos e médios laboratórios dedicados à produção de medicamentos de origem vegetal.

Atualmente, a cultura de calos e de suspensões celulares tem proporcionado a resolução de alguns problemas relacionados à utilização de plantas para extração de metabólitos secundários bioativos, principalmente, os de natureza fenólica, como os taninos, além de possibilitarem a compreensão das vias metabólicas e da atividade de algumas enzimas envolvidas nas rotas de biossíntese dessas substâncias (TANAKA et al., 1995; TANIGUCHI et al., 1998, 2002; ZHENTIAN et al., 1999; LIMA et al., 2008; NOGUEIRA et al., 2007; SANTANA et al., 2008; SOARES et al., 2007).

Os taninos são substâncias polifenólicas de sabor adstringente, encontrados no interior dos vacúolos vegetais e tradicionalmente empregados na medicina, devido a sua ação cicatrizante (LIMA et al., 1998). Segundo Santos \& Melo (2000) derivam-se de um intermediário biossintético comum, a fenilalanina, ou de seu precursor, o ácido chiquímico, sintetizados através da Rota do Chiquimato. Do ponto de vista fisiológico, são consideradas substâncias originadas do metabolismo do carbono (KORICHEVA et al., 1998).

Objetivou-se, no presente trabalho estabelecer um protocolo para a indução de calos em barbatimão, a partir de segmentos foliares e investigar os teores de fenóis e taninos totais nos calos produzidos.

\section{MATERIAL E MÉTODOS}

\section{Condições experimentais}

Frutos maduros de barbatimão foram coletados entre agosto e novembro de 2004, em área de cerrado sensu stricto, no município de Ijaci, sul de Minas Gerais. Após extraídas, as sementes foram tratadas com Benomyl a $2 \%$ e, após secagem foram armazenadas em câmara fria, por 30 dias, à temperatura de $4{ }^{\circ} \mathrm{C}$, no escuro. As sementes foram germinadas in vitro, segundo metodologia descrita por Vitor et al. (2005). Decorridos 60 dias de cultivo, plântulas foram utilizadas como fonte de explantes.

\section{Calogênese}

Segmentos foliares, de aproximadamente $0,25 \mathrm{~cm}^{2}$ foram inoculados em meio MS (MURASHIGE \& SKOOG, 1962), contendo $30 \mathrm{~g} \mathrm{~L}^{-1}$ de sacarose e suplementado com $2,4-\mathrm{D}(0 ; 4,52 ; 9,05 ; 18,10 \mu \mathrm{M})$ e $\operatorname{BAP}(0 ; 4,44 ; 8,88 ; 17,75$ $\mu \mathrm{M})$. Os meios foram solidificados com $7 \mathrm{~g} \mathrm{~L}^{-1}$ de ágar e

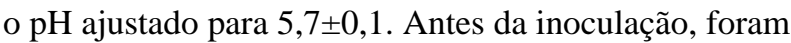
efetuados cortes na superfície dos segmentos foliares. Posteriormente, os explantes foram transferidos para sala de crescimento e incubados na ausência e presença de luz, à temperatura de $27 \pm 1^{\circ} \mathrm{C}$ e DFFFA de $45 \mathrm{mmol} \mathrm{m}^{-2} \mathrm{~s}$ ${ }^{1}$. Aos 15, 30, 45 e 60 dias avaliaram-se a porcentagem da área dos explantes coberta por calos e aos 60 dias avaliaram-se os números, matéria fresca e seca e os teores de fenóis e taninos totais em calos de barbatimão.

\section{Fenóis Totais}

Amostras de calos liofilizados foram trituradas em gral com pistilo e armazenadas em frascos fechados e protegidos da luz. Aproximadamente $400 \mathrm{mg}$ de calos triturados foram imersos em $5 \mathrm{~mL}$ de uma mistura de metanol:água (1:1), sendo o volume final do extrato completado para $25 \mathrm{~mL}$, à temperatura ambiente, sob maceração por $4 \mathrm{~h}$. Uma alíquota de $300 \mathrm{iL}$ do extrato foi utilizada para a determinação dos teores de fenóis totais, pelo método de Folin-Dennis (AOAC, 1970). As determinações foram feitas em triplicata e o resultado foi expresso em porcentagem de ácido tânico, por grama de calo seco.

\section{Taninos totais}

A determinação dos teores de taninos totais foi realizada por meio do "Método de Difusão Radial" (HAGERMAN, 1987). Um volume de $5 \mathrm{~mL}$ do extrato foi concentrado a $37{ }^{\circ} \mathrm{C}$ e posteriormente retomado com 0,5 $\mathrm{mL}$ de uma mistura de metanol:água (1:1). Uma alíquota de $15 \mathrm{~mL}$ foi utilizada para a determinação. Todas as determinações foram feitas em triplicata e o resultado foi expresso em porcentagem de tanino, por grama de calo seco. 


\section{Delineamento experimental e análises estatísticas}

O delineamento empregado foi o inteiramente casualizado com 20 repetições, compostas por 1 tubo contendo um explante cada um. Os dados foram submetidos à análise de variância e a comparação dos contrastes entre médias dos tratamentos foi feita utilizando-se o teste de Scott \& Knott (1974), a 5\% de probabilidade.

\section{RESULTADOS E DISCUSSÃO}

\section{Efeito do 2,4-D}

A calogênese iniciou-se 15 dias após a inoculação, em meios suplementados com 2,4-D, na presença de luz, com $75 \%$ das áreas dos explantes, em média, cobertas por calos. Na ausência do regulador não houve a indução de calos. O número de calos foi máximo e não variou com as concentrações de 2,4-D empregadas, indicando que a presença do regulador, nas concentrações testadas, não interferiu com a quantidade de calos induzidos.

Aos 60 dias após inoculação, maiores valores de matéria fresca e seca dos calos foram observados em meios contendo 9,05 $\mu \mathrm{M}$ e $18,10 \mu \mathrm{M}$ de 2,4-D, na presença de luz (Figuras 1A e B).

Maiores teores de fenóis totais foram verificados em calos induzidos em meios suplementados com 9,05 $\mu \mathrm{M}$ e 18,10 $\mu \mathrm{M}$ de 2,4-D, na ausência de luz (1\% em média), sendo esses rendimentos $50 \%$ superiores, em relação àqueles obtidos na presença de luz (Figura 2). Não se detectaram taninos nos calos formados. Os baixos rendimentos de fenóis totais observados nos calos induzidos, em relação ao explante inicial (EI) sugerem um mecanismo de degradação desses compostos no início do processo de calogênese, o que, segundo Yazaki et al. (1991), favorece novas divisões celulares e, consequentemente, evita a oxidação dos calos.

Avaliando-se simultaneamente os valores de matéria seca dos calos e os teores de fenóis totais em relação à concentração de 2,4-D no meio de cultivo, observa-se uma relação direta entre as duas variáveis (Figura 3), porém, um incremento de 50\% nos rendimentos de fenóis totais pode ser conseguido em calos com menores valores de matéria seca, induzidos na ausência de luz. Esses resultados são importantes do ponto de vista fisiológico e fitoquímico e evidenciam a possibilidade da utilização simultânea de 9,05 $\mu \mathrm{M}$ de 2,4-D e ausência de luz, na indução de calos em barbatimão.
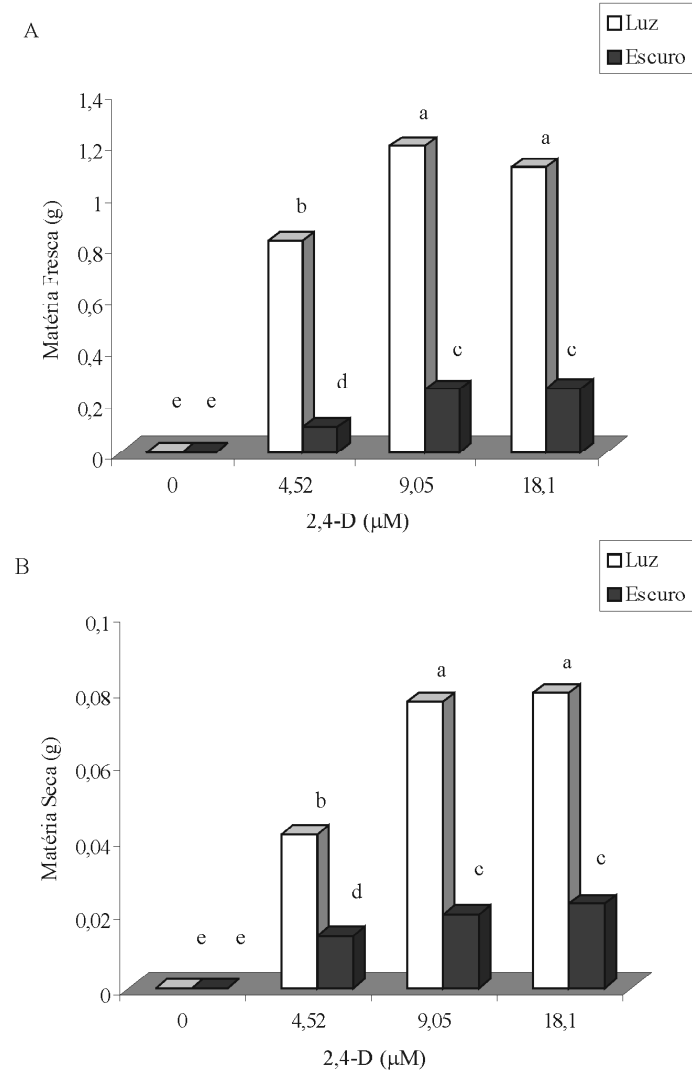

Figura 1 - Matéria fresca (A) e seca (B) dos calos de barbatimão, em diferentes concentrações de 2,4-D, na presença e ausência de luz. Médias seguidas pelas mesmas letras não diferem entre si, pelo teste de Scott-Knott, ao nível de $5 \%$ de probabilidade.

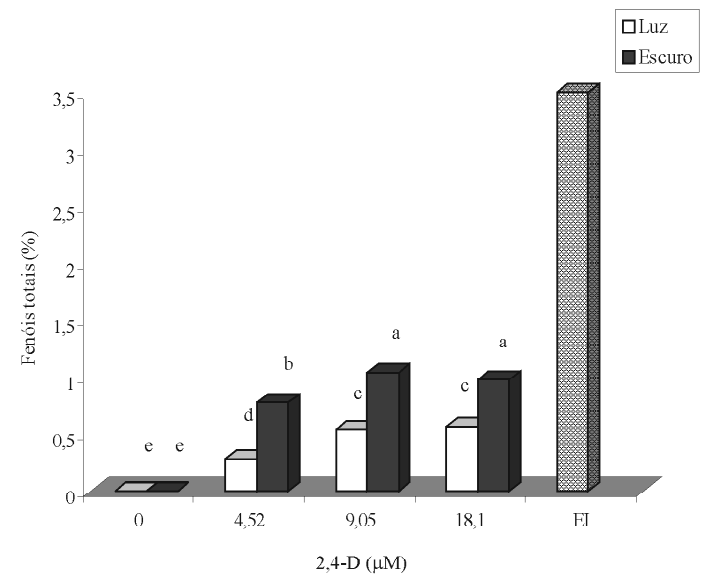

Figura 2 - Teores médios de fenóis totais em calos de barbatimão, cultivados em presença e ausência de luz, em diferentes concentrações de 2,4-D e no explante inicial (EI). Médias seguidas pelas mesmas letras não diferem entre si, pelo teste de Scott-Knott, ao nível de 5\% de probabilidade. 


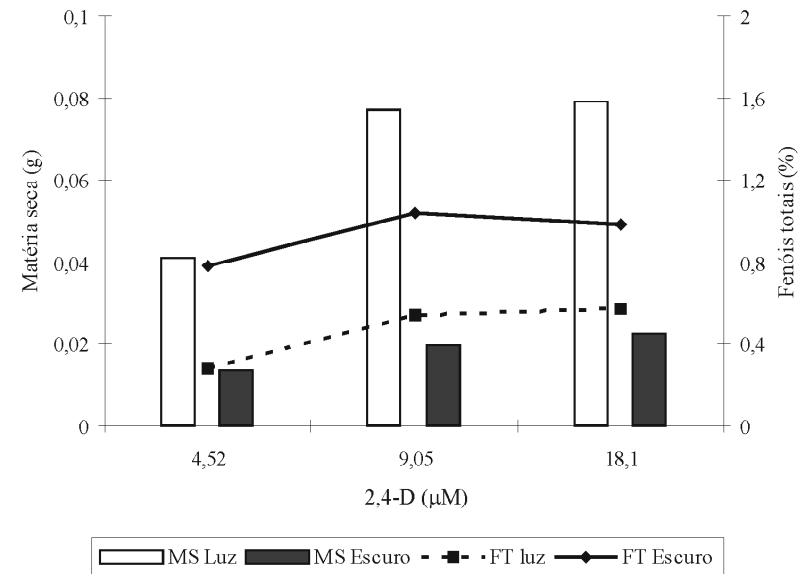

Figura 3 - Matéria seca (MS) e teores de fenóis totais (FT) em calos de barbatimão submetidos a concentrações de 2,4-D, na presença e ausência de luz. Valores médios.

O efeito do 2,4-D e da luz na indução e nos teores de compostos fenólicos em calos de espécies medicinais têm sido bem relatados atualmente e sugerem que variam de espécie para espécie. Segundo George (1996), o 2,4-D induz à transcrição de moléculas de RNA mensageiro capazes de codificar proteínas importantes para o crescimento e que podem induzir à proliferação celular desordenada, contudo, as divisões celulares iniciais do explante e o crescimento dos calos são, algumas vezes, inibidos pela presença de luz. Neera et al. (1992), em estudos realizados com Sapium sebiferum (L.) Roxb. demonstram que a presença de 4,52 $\mu \mathrm{M}$ de 2,4-D no meio de cultivo, na presença e ausência de luz foi eficiente na indução de calos nessa espécie. Os calos apresentaram padrão de crescimento três vezes maior, em relação àqueles cultivados em outros tratamentos e os teores de compostos fenólicos aumentaram subsequentemente a partir dos estágios iniciais de cultivo. Em Liquidambar styraciflua L., Neera et al. (1993) relatam que calos cultivados em meios suplementados com baixas concentrações de 2,4-D apresentaram menores valores de matéria seca, entretanto, a quantidade de compostos fenólicos aumentou rapidamente após sete semanas de cultivo, com o incremento do crescimento dos calos.

\section{Efeito do BAP}

A calogênese iniciou-se 30 dias após a inoculação, em meios acrescidos de BAP, na ausência de luz, com $25 \%$ das áreas dos explantes, em média, cobertas por calos. Não houve indução de calos na ausência do regulador e também na presença de luz. Maiores números de calos foram observados em meios contendo 4,44 e 8,88 $\mu \mathrm{M}$ de BAP, na ausência de luz.
Aos 60 dias após inoculação, calos induzidos em meios suplementados com 4,44 $\mu \mathrm{M}$ de BAP apresentaram maiores valores de matérias fresca e seca (Figura 4). Calos crescidos em meios contendo 4,44 e 17,75 $\mu \mathrm{M}$ de BAP apresentaram, em média, maiores teores de fenóis totais (em torno de 1,3\%) (Figura 5), valores esses que representam um incremento da ordem de $23 \%$ em relação àqueles observados em calos induzidos na presença de 2,4-D. Não se detectou a presença de taninos nos calos formados.

De acordo com os resultados obtidos, sugere-se a possibilidade de obtenção de calos com maiores valores de matérias fresca e seca, áreas do explante cobertas por calos e teores de fenóis totais, em maior número na presença de baixas concentrações de BAP e ausência de luz. Em calos de Sapium sebiferum, Neera et al. (1992) relatam reduções altamente significativas no crescimento em meios contendo altos níveis de citocininas, na ausência de luz.
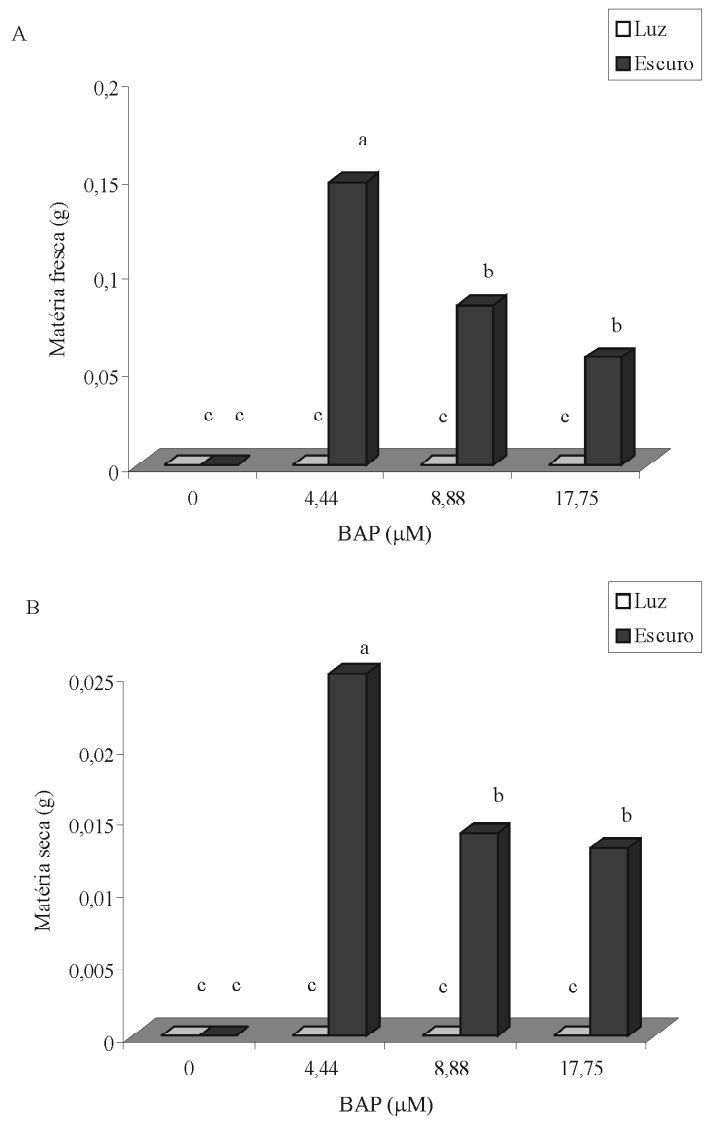

Figura 4 - Matéria fresca (A) e seca (B) dos calos de barbatimão, em diferentes concentrações de BAP, cultivados na presença e na ausência de luz. Médias seguidas pelas mesmas letras não diferem entre si, pelo teste de Scott-Knott, ao nível de 5\% de probabilidade. 


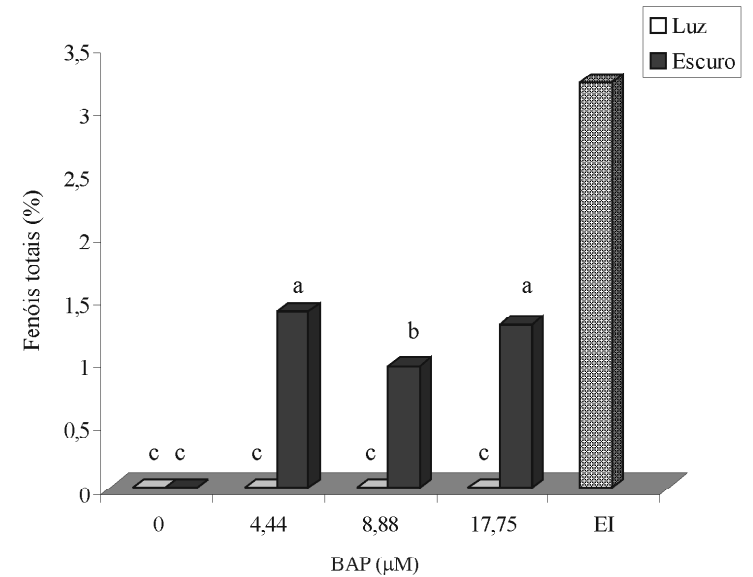

Figura 5 - Teores médios de fenóis totais em calos de barbatimão provenientes de meios com diferentes concentrações de BAP e no explante inicial (EI). Médias seguidas pelas mesmas letras não diferem entre si, pelo teste de Scott-Knott, ao nível de 5\% de probabilidade.

A utilização de BAP no meio de cultivo proporcionou a indução mais tardia dos calos e calos com menores valores de matéria fresca e seca e menores áreas dos explantes cobertas por calos, quando comparados com os tratamentos com 2,4-D. Entretanto, os teores de fenóis totais foram $23 \%$ superiores em relação àqueles obtidos em meios suplementados com 2,4-D.

Entre as vantagens da produção de compostos secundários in vitro, citam-se a maior facilidade de purificação dos extratos, em virtude da ausência de quantidade significativas dos pigmentos, resultando em redução dos custos de produção (BALADRIN \& KLOCKE, 1988). Entretanto, as culturas de tecidos produzem quantidades muito pequenas do composto desejado. Assim, novos estudos são necessários para ajustar um protocolo para o barbatimão, visando aperfeiçoar a produção de fenóis e taninos totais in vitro, sendo esse processo ainda difícil, visto que os estudos na área e com a referida espécie ainda são incipientes.

\section{CONCLUSÕES}

A calogênese foi mais eficiente e rápida em meios suplementados com 2,4-D.

A presença de 2,4-D no meio de cultivo favorece a indução de calos em barbatimão e proporciona a obtenção de maiores áreas do explante cobertas por calos e calos com maiores valores de matérias fresca e seca, na presença e ausência de luz.
Meios suplementados com baixas concentrações de BAP, na ausência de luz produziram calos com maiores rendimentos de fenóis totais e menores valores de matéria fresca e seca.

\section{AGRADECIMENTOS}

À Fundação de Amparo à Pesquisa do Estado de Minas Gerais (FAPEMIG), pelo suporte financeiro ao projeto e concessão de bolsa de iniciação científica.

\section{REFERÊNCIAS BIBLIOGRÁFICAS}

ALMEIDA, S. P. de; PROENÇA, C. E. B.; SANO, S. M.; RIBEIRO, J. F. Cerrado: espécies vegetais úteis. Planaltina: Embrapa-CPAC, 1998. 464 p.

ASSOCIATION OF OFFICIAL ANALYTICAL CHEMISTS. Official methods of the association of official analytical chemists. Washington, DC, 1970.

BALANDRIN, T.; KLOCKE, J. Medicinal, aromatic, and industrial materials from plant. In: BAJAJ, Y. P. S. (Ed.). Medicinal and aromatic plant 1. Berlim: Springer Verlag, 1988. p. 3-33. (Biotechnology in Agriculture and Forestry, 4).

FRANÇA, S. C.; DUARTE, I. B.; MORAES, R. M.; PEREIRA, A. M. S. Micropropagation of Stryphnodendron polyphythum. Plant Cell, Tissue and Organ Culture, Dordrecht, v. 42, p. 291-293, 1995.

GEORGE, E. F. Plant propagation by tissue culture: part 1, the technology. 2. ed. Edington: Exegetics, 1996. 1574 p.

\section{GOMES, G. A. C. Propagação in vitro da moreira} (Maclura tinctoria). 1999. 97 p. Dissertação (Mestrado em Fisiologia Vegetal) - Universidade Federal de Lavras, Lavras, 1999.

HAGERMAN, A. E. Radial diffusion method for determining tannin in plant extracts. Journal of Chemical Ecology, New York, v. 13, n. 3, p. 437-449, Mar. 1987.

KORICHEVA, J.; LARSSON, S.; HAUKIOJA, E.; KEINÄNEN, M. Regulation of woody plant secondary metabolism by resource availability: hypothesis testing by means of meta-analysis. Oikos, Copenhagen, v. 83, n. 2, p. 212-226, Nov. 1998. 
LIMA, J. C. S.; MARTINS, D. T. O.; SOUZA JÚNIOR, P. T. Experimental evaluation of stem bark

Stryphnodendron adstringens (Mart.) Coville for antinflamatory activity. Phytotherapy Research, v. 12, p. 218-220, 1998.

LIMA, E. C.; PAIVA, R.; NOGUEIRA, R. C.; SOARES, F. P.; EMRICH, E. B.; SILVA, Á. A. N. Callus induction in leaf segments of Croton urucurana Baill. Ciência e Agrotecnologia, Lavras, v. 32, n. 1, p. 17-22, jan/fev. 2008.

MURASHIGE, T.; SKOOG, F. A revised medium for rapid growth and biossays with tabacco tissue cultures. Physiologia Plantarum, Copenhagen, v. 15, n. 3, p. 473 497, 1962.

NEERA, S.; ARAKAWA, H.; ISHIMARU, K. Tannin production in Sapium sebiferum callus cultures. Phytochemistry, Oxford, v. 31, n. 12, p. 4143-4149, 1992.

NEERA, S.; ARAKAWA, H.; ISHIMARU, K. Tannin production in cell suspension cultures of Liquidambar styraciflua. Phytochemistry, Oxford, v. 32, n. 4, p. 921924, 1993.

NICIOLI, P. M. Micropropagação e aspectos fitoquímicos de calos de barbatimão [Stryphnodendron adstringens (Mart.) Coville]. 2006. 89 p. Dissertação (Mestrado em Fisiologia Vegetal) - Universidade Federal de Lavras, Lavras, 2006.

NOGUEIRA, R. C.; PAIVA, R.; OLIVEIRA, L. M.; SOARES, G. DE A.; SOARES, F. P.; CASTRO, A. H. F.; PAIVA, P. D. DE O. Indução de calos em explantes foliares de murici-pequeno (Byrsonima intermedia A. Juss.). Ciência e Agrotecnologia, Lavras, v. 31, n. 2, p. 366-370, mar/abr. 2007.

SANTANA, J. R. F. DE.; PAIVA, R.; PEREIRA, F. D.; OLIVEIRA, L. M. DE.; Estímulo do comportamento fotoautotrófico durante o enraizamento in vitro de Annona glabra L., I. desenvolvimento do sistema radicular e da parte aérea. Ciência e Agrotecnologia, Lavras, v. 32, n. 1, p. 80-86, jan/fev. 2008.

SANTOS, S. da C.; MELLO, J. C. P. de. Taninos. In: SIMÕES, C. M. O. et al. Farmacognosia: da planta ao medicamento. 2. ed. rev. Porto Alegre: UFRGS, 2000. p. 517-544.

SCOTT, A. J.; KNOTT, M. A cluster analysis method for grouping means in the analysis of variance. Biometrics, Washington, v. 30, n. 3, p. 507-512, 1974.

SILVA FILHO, P. V. Plantas do cerrado produtoras de matéria tintorial. Informe Agropecuário, Belo Horizonte, v. 16, n. 173, p. 28-32, 1992.

SOARES, F. P.; PAIVA, R.; ALVARENGA, A. A. DE.; NOGUEIRA, R. C.; EMRICH, E. B.; MARTINOTTO, C. Organogênese direta em explantes caulinares de mangabeira (Hancornia speciosa Gomes). Ciência e Agrotecnologia, Lavras, v. 31, n. 4, p. 1048-1053, jul/ago. 2007.

TANAKA, N.; SHIMOMURA, K.; ISHIMARU, K. Tannin production in callus culture of Quercus acutissima. Phytochemistry, Oxford, v. 40, n. 4, p. 11511154, 1995.

TANIGUCHI, S.; IMAYOSHI, Y.; YABU-UCHI, R.; ITO, H.; HATANO, T.; YOSHIDA, T. A macrociclic ellagitannin trimer, oenotherin $\mathrm{T}_{1}$ from Oenothera species. Phytochemistry, Oxford, v. 59, p. 191-195, 2002.

TANIGUCHI, S.; NAKAMURA, N.; NOSE, M.; TAKEDA, S.; YABU-UCHI, R.; ITO, H.; YOSHIDA, T.; YAZAKI, K. Production of macrociclic ellagitannin oligomers by Oenothera laciniata callus cultures. Phytochemistry, Oxford, v. 48, n. 6, p. 981-985, 1998.

VITOR, S. M. M. et al. Germinação in vitro e efeito do 2,4-D e BAP na indução de calogênese e nos teores de fenóis e taninos totais em Stryphnodendron adstringens (Mart.) Coville. 2005. Disponível em: <http:// wwww.fevale.edu.br/seminário/cd/files/pdf/1884.pdf Acesso em: 16 maio 2006.

YAZAKI, K.; YOSHIDA, T.; OKUDA, T. Tannin production in cell suspension cultures of Geranium thunbergii. Phytochemistry, Oxford, v. 30, n. 2, p. 501503, 1991.

ZHENTIAN, L.; JERVIS, J.; HELM, R. F. C-glycosidic ellagitannins from white oak heartwood and callus tissues. Phytochemistry, Oxford, v. 51, p. 751-756, 1999. 